Ecology

\title{
Effects of establishment of grazing areas on diversity of amphibian communities in tropical evergreen forests and mountain cloud forests of the Sierra Madre Oriental
}

\author{
Efecto del establecimiento de áreas de pastoreo en la diversidad de las comunidades de anfibios \\ en bosques tropicales perennifolios y bosques mesófilos de montaña en la Sierra Madre Oriental \\ Luis Manuel Badillo-Saldaña ${ }^{a}$, Aurelio Ramírez-Bautista ${ }^{a}, *$, Larry David Wilson ${ }^{b}$ \\ ${ }^{a}$ Laboratorio de Ecología de Poblaciones, Centro de Investigaciones Biológicas, Instituto de Ciencias Básicas e Ingeniería, Universidad Autónoma del Estado \\ de Hidalgo, Km 4.5 carretera Pachuca-Tulancingo, 42184 Mineral de la Reforma, Hidalgo, Mexico \\ ${ }^{\mathrm{b}}$ Centro Zamorano de Biodiversidad, Escuela Agrícola Panamericana, Zamorano, Km 30 carretera de Tegucigalpa-Danlí, 93 San Antonio Oriente, \\ Francisco Morazán, Honduras \\ Received 11 March 2015; accepted 30 September 2015 \\ Available online 12 February 2016
}

\begin{abstract}
The establishment of grazing areas in humid tropical environments is one of the causes of amphibian population decline. This work evaluates the consequences of the establishment of grazing areas on amphibian communities in an area of the Sierra Madre Oriental using analyses of alpha and beta diversity. Sampling was conducted at 28 locations, 7 in tropical evergreen forest (TEF), 7 in mountain cloud forest (MCF), 7 in tropical grazing areas (TGA), and 7 in cloud forest grazing areas (CFGA) using the method of direct sampling. Amphibian diversity is reduced when the grazing areas are established in tropical environments (TGA, 8 species; 7.1 effective species and TEF, 10 species; 7.7 effective species); in contrast, the CFGA has a greater diversity (11 species; 9.3 effective species) compared with MCF ( 8 species; 3.9 effective species). The most dissimilar composition was found between the 2 communities of undisturbed forests (MCF-TEF; Jaccard dissimilarity 0.78). Establishment of grazing areas in TEF strongly influences the reduction of amphibian populations when compared with MCF.

All Rights Reserved (c) 2015 Universidad Nacional Autónoma de México, Instituto de Biología. This is an open access item distributed under the Creative Commons CC License BY-NC-ND 4.0.
\end{abstract}

Keywords: Anura; Caudata; Alpha and beta diversity; Hidalgo; Mexico

\section{Resumen}

El establecimiento de áreas de pastoreo en ambientes húmedos tropicales es una de las causas de la reducción de las poblaciones de anfibios. Este trabajo evalúa las consecuencias del establecimiento de las áreas de pastoreo en las comunidades de anfibios en un área de la Sierra Madre Oriental por medio del análisis de diversidad alfa y beta. El muestreo se realizó en 28 localidades; 7 de bosque tropical perennifolio (TEF), 7 de bosque mesófilo de montaña (MCF) no alterado, 7 en áreas de pastoreo tropicales (TGA) y 7 en áreas de pastoreo de bosque mesófilo (CFGA), usando el método de muestreo directo. La diversidad de anfibios se reduce cuando las áreas de pastoreo se establecen en ambientes tropicales (TGA, 8 especies; 7.1 especies efectivas y TEF, 10 especies; 7.7 especies efectivas); en contraste, el CFGA presenta una mayor diversidad (11 especies; 9.3 especies efectivas) comparado con el MCF (8 especies; 3.9 especies efectivas). La composición más disímil se encontró entre las comunidades de los bosques conservados (MCF-TEF, 0.78 disimilitud de Jaccard). El establecimiento de áreas de pastoreo en los TEF influye con mayor intensidad en la reducción de las poblaciones de anfibios, en comparación con el MCF.

Derechos Reservados @ 2015 Universidad Nacional Autónoma de México, Instituto de Biología. Este es un artículo de acceso abierto distribuido bajo los términos de la Licencia Creative Commons CC BY-NC-ND 4.0.

Palabras clave: Anura; Caudata; Diversidad alfa y beta; Hidalgo; México

\footnotetext{
* Corresponding author.

E-mail address: ramibautistaa@gmail.com (A. Ramírez-Bautista).
}

Peer Review under the responsibility of Universidad Nacional Autónoma de México. 


\section{Introduction}

Habitat transformation directly affects the entirety of diversity (Pavlov \& Bukvareva, 2007). Because of habitat disturbance, the majority of ecosystems have undergone great changes in landscape makeup; it is estimated that worldwide between 20 and $75 \%$ of the original vegetation has been altered (Pavlov \& Bukvareva, 2007). Such disturbance relegates an increasing number of species to live in fragmented landscapes dominated by anthropogenic activities (Bawa et al., 2004; Foley et al., 2005). Alterations of the environment cause important ecological changes at all levels (Glor, Flecker, Benard, \& Power, 2001). For example, local deforestation due to agriculture or livestock production produces degradation and loss of soil, changes in microclimate, and biodiversity loss (De Sá, 2005; Wanger et al., 2010). Because of such simplification of natural environments, there is a great reduction of areas for preservation and development of biodiversity (Cardinale et al., 2012); this process particularly might affect the presence and abundance of amphibians (Jansen \& Healey, 2003).

On a global scale, the creation of grazing areas and hydrologic alteration has been shown to have adverse effects on amphibian communities, principally in tropical moist sites (Jansen \& Healey, 2003; Pineda \& Halffter, 2003). In these areas, local effects created by the transformation of natural environments to grazing areas form barriers that prevent the natural flow of amphibian populations (De Sá, 2005). These barriers prevent gene flow among populations, in addition to increasing mortality rates and infections, and the reduction of the ability for re-colonization of amphibians (Cushman, 2006; Jansen \& Healey, 2003).

Some surveys have shown that amphibians can be good models to assess environmental quality, because they present physiological and ecological characteristics that make them susceptible to changes that occur as a result of the disturbance, for example deforestation processes (Cushman, 2006; Jansen \& Healey, 2003; Pineda \& Halffter, 2003). Studies show that there is a positive relationship between canopy cover and amphibian diversity (Pineda \& Halffter, 2003). Cushman (2006) also observed that the reduction in canopy cover reduces vagility, especially in the juvenile stages. These stages are crucial for the reproduction of amphibians, because this is when movement occurs into new water bodies for reproduction (Cushman, 2006; Jansen \& Healey, 2003). Therefore, the adverse conditions generated by grazing areas restrict amphibians to sites with high humidity (Jansen \& Healey, 2003), thus limiting their mobility. In addition, reduction in the populations of some amphibians species is directly related to the intensity of grazing on pastureland; therefore, amphibian diversity decreases when grazing intensity is high (Jansen \& Healey, 2003). This relationship results because cattle directly influence the compaction and erosion of soil, growth and selection of grasses in the grazing areas, and the quality and quantity of water available for amphibians during the breeding season (Cushman, 2006; Jansen \& Healey, 2003).

In Mexico, the process of land conversion of forests to grazing areas has a lengthy history and recently it has increased significantly in humid tropical landscapes (Lira-Noriega, Guevara,
Laborde, \& Sánchez-Ríos, 2007). In this country, however, there are few studies that aim to assess the effects of grazing areas on the diversity of amphibians (Pineda \& Halffter, 2003; Urbina-Cardona \& Reynoso, 2005), particularly in areas where mountain cloud forests and evergreen tropical forests converge. Therefore, the goal of this study is to assess the consequences of grazing areas on the amphibian communities in tropical evergreen forests and mountain cloud forests in an area of the Sierra Madre Oriental in northern Hidalgo by analyzing the alpha (Hill's numbers; Jost, 2006) and beta diversity (Replacement and richness difference; Legendre, 2014). Studies show that these analyses have proved useful for comparing the diversity among 2 or more communities (Legendre, 2014; Moreno, Barragán, Pineda, \& Pavón, 2011).

\section{Materials and methods}

The sampling sites were located within an area of the Sierra Madre Oriental (SMO) in northern Hidalgo, specifically in the area comprising the municipality of Tepehuacán de Guerrero (Fig. $1 ; 20^{\circ} 56^{\prime}$ and $21^{\circ} 12^{\prime} \mathrm{N}, 98^{\circ} 44^{\prime}$ and $98^{\circ} 58^{\prime} \mathrm{W}$ ). This area is dominated mainly by a warm humid climate with rainfall throughout the year, elevational cline ranges from 200 to $2,200 \mathrm{~m}$, with an annual rainfall of 1,100 to $2,200 \mathrm{~mm}$ and a mean annual temperature of $18^{\circ} \mathrm{C}$ in the highlands and $28^{\circ} \mathrm{C}$ in the lowlands (Inegi, 2009). The study area was originally covered by continuous forest. Tropical evergreen forest dominates the hillsides and lower parts of the mountains, whereas the higher parts are covered by mountain cloud forest; however, in the last few decades these forests have been destroyed by anthropic effect to establish grazing areas, which has generated vegetation patches in various stages of regeneration (Ponce-Vargas, Luna-Vega, Alcántara-Ayala, \& Ruiz-Jiménez, 2006).

Tropical evergreen forest is distributed in the northern portion of Hidalgo state (Villavicencio-Nieto \& Pérez-Escandón, 2005), near the border with San Luis Potosí (Rzedowski, 2006). Puig (1991) referred to this as semi-deciduous tropical forest; however, Rzedowski (2006) grouped this vegetation type within tropical evergreen forest, because tropical evergreen forest and semi-deciduous tropical forest share similar structural elements. In our study area, this vegetation was characterized by trees over $20 \mathrm{~m}$ in height and a rich diversity of woody climbing plants, orchids, and bromeliads (Puig, 1991). In this type of vegetation, the patterns of abundance of tree species makes it difficult to determine the dominant tree species; however, the canopy is mainly composed by trees of the genera Brosimum, Bursera, Ceiba, Coccoloba, Ficus, and Dendropanax (Puig, 1991).

Mountain cloud forest is characterized by presence of fog during most of the year (Hamilton, Juvik, \& Scatena, 1995); neartic and neotropical elements converge in this kind of forest; therefore, this area represents a highly complex environment in terms of vegetation, which also varies along the length of its geographic distribution (Conabio, 2010; Ruiz-Jiménez, TéllezValdez, \& Luna-Vega, 2012). Thus, MCF from the northern region of the state of Hidalgo is characterized by a dense forest, with trees over 15-35 m height. The most common trees are of 


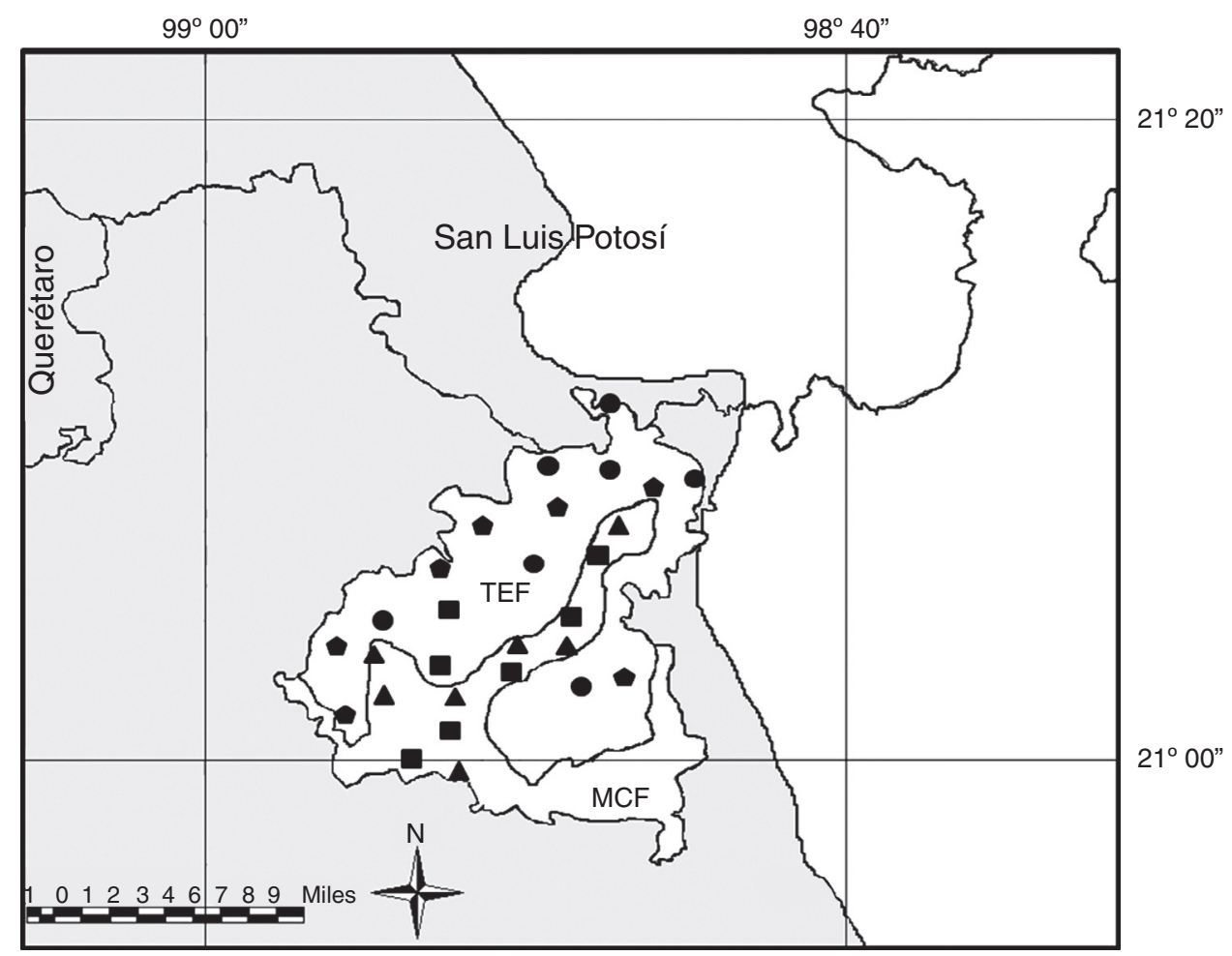

Figure 1. Study area. In the gray SMO, area dominated by tropical evergreen forest (TEF), area dominated by mountain cloud forest (MCF); the pentagons represent the tropical evergreen forest localities, circles are tropical grazing areas, triangles are cloud forest grazing areas, and squares are the cloud mountain forest localities.

the genera Liquidambar, Alnus, Clethra, Corpinus, Sauravia, Podocarpus, and Quercus (Ruiz-Jiménez et al., 2012).

For selection of grazing areas, we considered those with surrounding arboreal elements or remnants, as well as the altitude at which they were found; therefore, the grazing areas in tropical environments (TGA) were those that were covered in TEF at an elevation $<800 \mathrm{~m}$ asl, whereas the grazing area of cloud forest (CFGA) were those that were embedded within the cloud forest at an elevation $>800 \mathrm{~m}$ asl.

This study was carried out March, May, August, and November of 2011 and April, July, and October of 2012. We sampled 7 sites for each of the TEF, MCF, TGA and CFGA habitats for a total of 28 locations. Each of the localities was separated from the others by approximately 1 mile $(1.5 \mathrm{~km})$ in order to obtain independent samples, taking into consideration the natural history of the resident amphibians (Cushman, 2006). During each survey in the study areas, we visited all analyzed environments. In these, we selected grazing areas and patches of native vegetation that were of similar size ( $\geq 10 \mathrm{ha}$ ). At each site, we randomly selected 4 transects of approximately $900 \mathrm{~m}$ in length with a variable width. Due to differences in arboreal complexity, the limit of search was limited to $2 \mathrm{~m}$ above ground level. We conducted 2 sampling regimes, one in the morning (09:00-14:00 h) and the other later in the day (16:00-21:00 h), and avoided the edges between habitat types. Each site was sampled by 4 people by a direct sampling method, which consisted of a review of all potential microhabitats (below $2 \mathrm{~m}$ ) used by amphibians, according to their known natural history (Amador, 2010; Manzanilla \& Péfaur, 2000). For each habitat type, we invested a sampling effort of 280 man-hours, obtaining a total sampling effort of 1,120 man-hours.

Most species were identified during the fieldwork. Those species we were unable to identify in the field were transported to the Laboratorio de Ecología de Poblaciones of the Universidad Autónoma del Estado de Hidalgo (UAEH). Specimens were collected under the scientific permit provided by Semarnat (\# SGPA/DGVS/02726/10). The small samples collected were euthanized by the freezing method and later were fixed in formalin (10\%), and finally were stored in alcohol $75 \%$ in the collection of amphibians and reptiles of UAEH. Specimens were identified with dichotomous keys and the scientific names were updated following the most recent literature on the study group, for example, Wilson, Mata-Silva, \& Johnson (2013), Wilson, Johnson, \& Mata-Silva (2013) and Streicher et al. (2014).

\section{Data analysis}

Species accumulation curves were performed using the program EstimateS V 9.1 (Colwell, 2005), in order to assess species richness of TEF, MCF, TGA, and CFGA, and to determine whether the completeness of the inventory allowed comparisons among them (Carbajal-Cogollo \& Urbina-Cardona, 2008). Completeness of the inventory was assessed with the nonparametric estimator ACE. This estimator divides species into 2 categories: abundant, when a sample has more than 10 individuals recorded; and rare, when a sample contains 10 or fewer individuals. The ACE estimator is based on the proportion of 
rare species in the sample (singletons) to determine the missing species in the community, so abundant species do not provide information about the missing species (Chao \& Shen, 2003).

Rarefaction curves were performed with the version 3.1 PAST program (Hammer, Harper, \& Ryan, 2001) to evaluate the amphibians richness, taking into account the same number of individuals to standardize data (Moreno, 2001). To measure equity in each habitat, curves of rank-abundance were developed using the relative abundance of each species (pi), with the goal of observing species dominance and the species turnover among habitats. The inverse of the Simpson index $\left(C_{\text {inv }}\right)$ was obtained to determine the dominance for each community; this kind of index was selected because it is influenced by the abundance of the species and because it is independent of species richness (Feinsinger, 2003).

In order to calculate alpha diversity, we used the diversity index of Hill's numbers first order $\left({ }^{1} D\right.$; Jost, 2006; Moreno et al., 2011), which is based on the effective number of species and considers the relative abundance of the species in the community by using the Shannon exponential index expressed by the formula ${ }^{1} D=\exp (H)$.

We evaluated beta diversity with the Jaccard dissimilarity index based on presence-absence data; this index ranges from zero (identical communities) to 1 (different communities; Legendre, 2014). Likewise, we analyzed the beta diversity, dividing it into 2 components, replacement and richness difference (Legendre, 2014), with the purpose to observe in a more intuitive way the species turnover and the composition of amphibian communities.

\section{Results}

In this study, we recorded 157 individuals of amphibians belonging to 18 species included in 11 genera, 6 families, and 2 orders (Anura and Caudata; Table 1). Higher species richness was recorded in CFGA (11 species) with a completeness inventory of $100 \%$, whereas the lowest richness was obtained in the TGA $(100 \%)$ and the MCF $(80.4 \%)$, with 8 species each (Table 2).

In assessing species richness considering the same number of individuals, we observed that the most diverse community is the CFGA. The result for MCF, however, should be taken with caution because for this vegetation type we did not observe that the curve reached an asymptote (Fig. 2); in addition, the inventory completeness was below $80 \%$.

We observed the greatest evenness in the CFGA community $\left(C_{\mathrm{inv}}=0.902\right)$, in which rare species occur, such as Pseudoeurycea gigantea and $P$. cephalica, as well as common
Table 1

Amphibian species recorded within 4 study areas located in northern Hidalgo, Mexico, arranged according to families. See text for explanations of abbreviations.

\begin{tabular}{|c|c|c|c|c|}
\hline \multirow[t]{2}{*}{ Species } & \multicolumn{4}{|c|}{ Study areas } \\
\hline & MCF & CFGA & TEF & TGA \\
\hline \multicolumn{5}{|l|}{ Family Bufonidae } \\
\hline Incilius nebulifer & 1 & 5 & 5 & 3 \\
\hline I. valliceps & - & 7 & 6 & 6 \\
\hline Rhinella marina & - & 0 & 3 & 4 \\
\hline \multicolumn{5}{|l|}{ Family Craugastoridae } \\
\hline Craugastor decoratus & - & 3 & - & - \\
\hline C. rhodopis & 20 & 7 & - & - \\
\hline \multicolumn{5}{|l|}{ Family Eleutherodactylidae } \\
\hline Eleutherodactylus longipes & - & 4 & - & - \\
\hline E. verrucipes & - & - & 2 & - \\
\hline \multicolumn{5}{|l|}{ Family Hylidae } \\
\hline Charadrahyla taeniopus & 6 & - & - & - \\
\hline Ecnomiohyla miotympanum & 1 & 7 & 14 & 5 \\
\hline Plectrohyla charadricola & - & - & 5 & - \\
\hline Smilisca baudinii & 2 & 2 & - & 5 \\
\hline Trachycephalus typhonius & - & - & 1 & - \\
\hline \multicolumn{5}{|l|}{ Family Ranidae } \\
\hline Lithobates berlandieri & 2 & 4 & 5 & 6 \\
\hline L. johni & - & - & 5 & 1 \\
\hline L. spectabilis & 1 & 3 & 1 & 2 \\
\hline \multicolumn{5}{|l|}{ Family Plethodontidae } \\
\hline Pseudoeurycea bellii & 1 & - & - & - \\
\hline P. gigantea & - & 1 & - & - \\
\hline P. cephalica & - & 1 & - & - \\
\hline Total individuals/Species & $34 / 8$ & $44 / 11$ & $47 / 10$ & $32 / 8$ \\
\hline
\end{tabular}

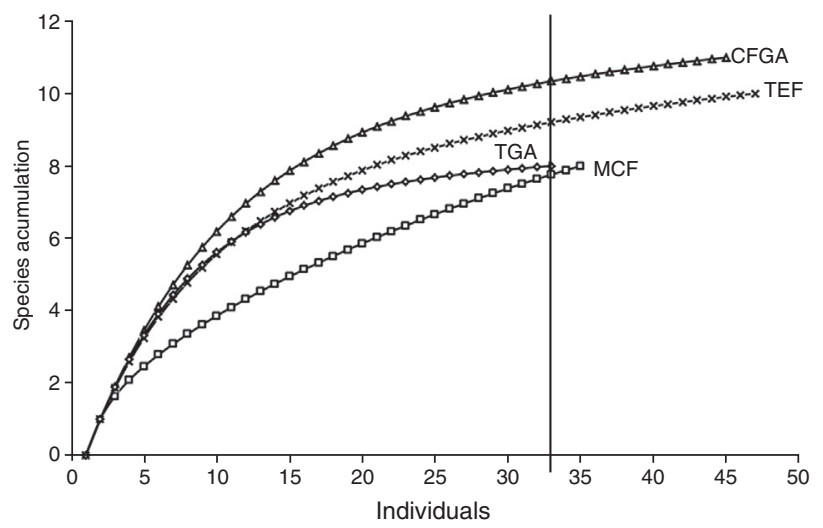

Figure 2. Rarefaction curves. The black line indicates the minimum number of individuals among communities. The MCF data should be regarded with caution since it did not reach an asymptote.

Table 2

Species richness (observed species), completeness percentage according to the estimator ACE, and alpha diversity (effective species) for each vegetation type.

\begin{tabular}{lcccc}
\hline Communities & Observed species & Estimated species ACE & $\begin{array}{l}\text { Completeness } \\
\text { percentage inventory }\end{array}$ & Alpha diversity \\
\hline MCF & & & 80 & 3.9 \\
CFGA & 8 & 10 & 100 & 9.3 \\
TEF & 11 & 11 & 100 & 7.7 \\
TGA & 10 & 10 & 100 & 7.1 \\
\hline
\end{tabular}




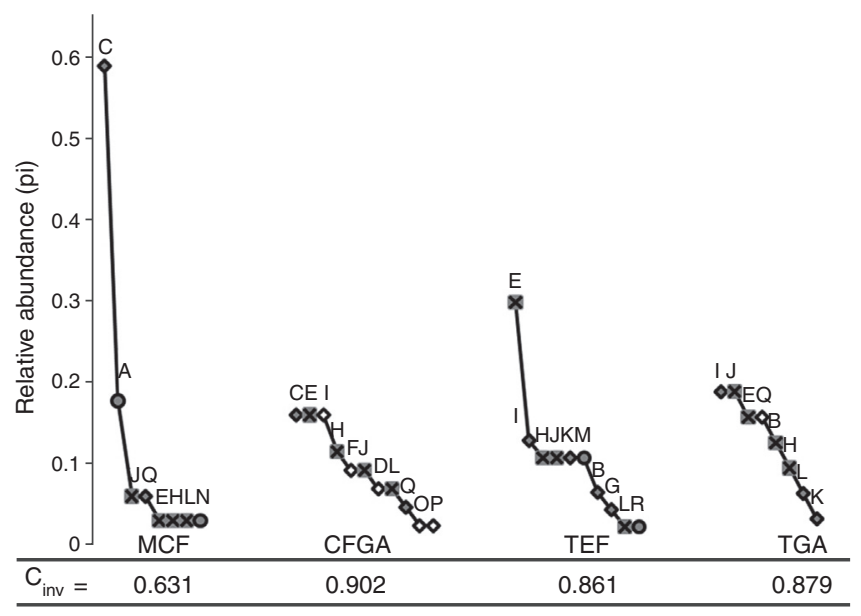

Figure 3. Abundance-range curves. The circles represent species that are lost when grazing areas are established, boxes represent species that are present in all communities, and the black diamond shows the other species. (A) Charadrahyla taeniopus; (B) Rhinella marina; (C) Craugastor rhodopis; (D) C. decoratus; (E) Ecnomiohyla miotympanum; (F) Eleutherodactylus longipes; (G) E. verrucipes; (H) Incilius nebulifer; (I) I. valliceps; (J) Lithobates berlandieri; (K) L. johni; (L) L. spectabilis; (M) Plectrohyla charadricola; (N) Pseudoeurycea bellii; (O) P. gigantea; (P) P. cephalica; (Q) Smilisca baudinii; (R) Trachycephalus typhonius.

species, such as Craugastor rhodopis and Ecnomiohyla miotympanum. We determined that the community with the lowest evenness is the $\operatorname{MCF}\left(C_{\mathrm{inv}}=0.631\right)$, with a single very abundant species (Craugastor rhodopis) and 4 rare species (Ecnomiohyla miotympanum, Incilius nebulifer, Lithobates spectabilis, and Pseudoeurycea bellii). The communities with the greatest evenness were observed within grazing areas from both the TGA $\left(C_{\mathrm{inv}}=0.879\right)$ and CFGA (Fig. 3$)$. One species is lost (Charadrahyla taeniopus) when grazing areas are set in $\mathrm{MCF}$, and 3 species (Plectrohyla charadricola, Eleutherodactylus verrucipes, and Trachycephalus typhonius) in TEF. On the other hand, CFGA showed 5 especies (I. valliceps, C. decoratus, E. longipes, $P$. gigantea, and $P$. cephalica) that were not detected within MCF; whereas in TGA we recorded 1 species (Smilisca baudinii) that was not observed in TEF (Fig. 3). The greatest diversity of species was recorded in the CFGA, with 9.3 effective species (Table 1).

The most dissimilar species composition occurred between the preserved forests MCF-TEF, whereas the least dissimilar composition was between the communities of TEF-TGA (Fig. 4). The higher replacement was observed within communities of MCF-TGA that showed $100 \%$ of the beta diversity, whereas within communities corresponding to the sets of MCF-CFGA and TGA-CFGA the lowest percentage richness difference $(42.85 \%)$ was exhibited.

\section{Discussion}

Habitat loss is the most important factor in reducing amphibian populations (Jansen \& Healey, 2003). In this regard, disturbed environments such as grazing areas restrict amphibian distributions (Cushman, 2006), reducing the ability of juveniles to disperse to search for new water bodies in which to reproduce

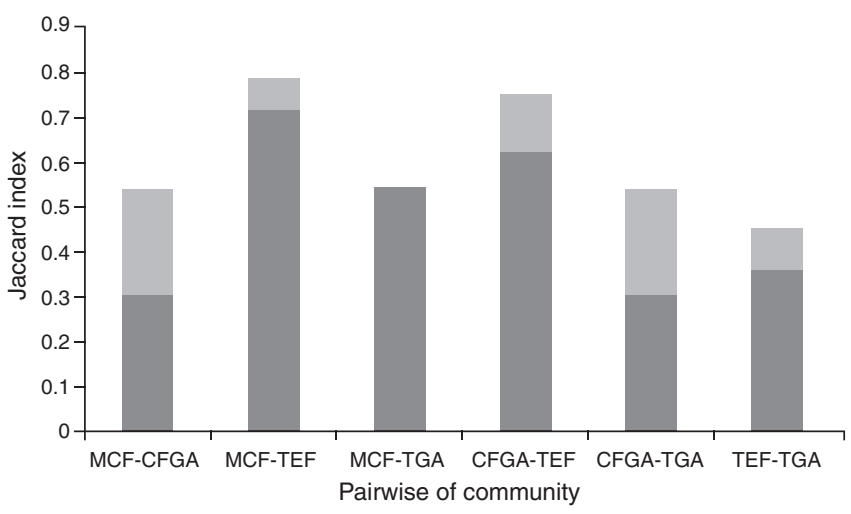

Figure 4. Full bar is the total beta (Jaccard dissimilarity), the fragmented dark gray line represents the replacement and the light gray line corresponds to richness difference.

eventually, consequently reducing gene flow among populations (Cushman, 2006). In the northern regions of the state of Hidalgo, the establishment of grazing areas for extensive livestock raising has had different effects on amphibian communities. On one side, the disturbance seems to increase the diversity of species in the mountain cloud forest; on the other side, amphibian diversity decreases in the tropical evergreen forest. In both cases, however, exclusively interior forest species, such as Charadrahyla taeniopus, which is considered a restricted cloud forest species are declining with the creation of grazing areas, (Canseco-Márquez \& Gutiérrez-Mayen, 2006), as well as species of the family Eleutherodactylidae that live in the interior of tropical forests (Canseco-Márquez \& Gutiérrez-Mayén, 2010).

Inside tropical forests, like TEF, the climatic conditions, such as humidity and temperature, are more stable than in the grazing areas (Urbina-Cardona \& Lodoño, 2003). In these environments, the allocation of resources among amphibian species is determined by the availability of water; therefore, species are interacting or competing along a space-time gradient within the habitat (Cáceres-Andrade \& Urbina-Cardona, 2009). Due to the evaporation process that occurs during the day within the grazing areas, these interactions are restricted only to those species that can withstand these kind of conditions, for example, Rhinella marina, which is characterized by skin properties and reproductive habits that allow them to live and reproduce in dry and highly-polluted environments (Cáceres-Andrade \& Urbina-Cardona, 2009). Other species well suited for living in grazing areas are Lithobates berlandieri, Smilisca baudinii and Incilius valliceps (Canseco-Márquez \& Gutiérrez-Mayen, 2006). Therefore, establishment of grazing areas reduces species richness, particularly affecting species that show preference for sites with abundant leaf litter (Urbina-Cardona \& Lodoño, 2003; Cáceres-Andrade \& Urbina-Cardona, 2009).

Cloud forest from this region shows stable humidity conditions and low seasonal variation throughout the year (RuizJiménez et al., 2012), which creates favorable conditions for the establishment for many amphibians species (Gual-Díaz \& Goyenechea, 2014). In this habitat, the moisture present in all canopy levels allows amphibians to inhabit several microhabitats. In Mexico, there are 183 species of amphibians that inhabit 
this forest type, with the families Hylidae and Plethodontidae the best represented (Gual-Díaz \& Goyenechea, 2014); these families show preference for arboreal microhabitats. In this paper, the MCF presented a smaller amphibian richness compared to that seen in other studies (Canseco-Márquez \& Gutiérrez-Mayen, 2006; Gual-Díaz \& Goyenechea, 2014; Pineda \& Halffter, 2003) and the lowest richness when compared with the other habitats assessed in this study (3.9 effective species). However, this phenomenon could be due to the sampling method used because we only sampled up to $2 \mathrm{~m}$ in height in the canopy, and some arboreal species recorded in previous studies in our area may not have been recorded in this study, such as Chiropterotriton sp. (Mendoza-Quijano, Quijano-Manilla, \& Mendoza-Paz, 2006). Therefore, the results obtained in this work for the cloud forest should be taken with caution. In contrast, in the CFGA, diversity seems to increase because within this environment there are some species with tropical affinities that are able to inhabit this environment, such as Incilius valliceps and I. nebulifer (Canseco-Márquez \& Gutiérrez-Mayen, 2006; Fig. 3), which are resource-generalist species, and are able to withstand disturbed environments (Santos-Barrera \& Urbina-Cardona, 2011). In addition, there are native forest species that can tolerate the conditions present in grazing areas, for example Craugastor rhodopis that inhabits both the MCF and CFGA and is one of the dominant species (Fig. 3). Although these results are contrary to those reported by Pineda and Halffter (2003), who found that amphibian diversity is reduced by grazing areas in cloud forests in northern Veracruz. Our results could be due to the proximity of the MCF and the TEF, which was not the case in northern Veracruz. These results suggest that the composition of amphibian communities present in grazing areas embedded in the cloud forests may be strongly influenced by the landscape (Pineda \& Halffter, 2003).

In the MCF and the TEF, the modification of the sites with original vegetation promotes an exchange in richness and abundance of amphibian species compared to the forest interior (Fig. 4). For example, in the MCF established grazing areas promote replacement that could increase species richness. This pattern is similar to those seen in other biological groups from this region; for example, in tropical environments, the greatest richness of beetles occurs within the forest, whereas in the cloud forests richness increases within the grazing areas (Barragán, Moreno, Escobar, Bueno-Villegas, \& Halffter, 2014). In temperate and arid environments, where amphibian populations are naturally low, the consequences of the establishment of grazing areas are inconclusive (Jansen \& Healey, 2003; Mensing, Galatowitsch, \& Tester, 1998). Studies conducted to evaluate the effect of grazing areas on amphibian communities, have shown that physiological and ecological variations unique to each species produced diverse results (Pineda \& Halffter, 2003). Therefore, it is necessary to conduct studies that consider physiological and ecological aspects of each amphibian species, because each species responds in different ways to the disturbed environments (Cáceres-Andrade and Urbina-Cardona, 2009; Jansen \& Healey, 2003).

According to our results, amphibians are greatly affected when grazing areas are established in tropical evergreen forest environments, whereas in cloud forests further studies using complementary methods of sampling are needed to confirm whether the species richness increases or decreases. The establishment of grazing areas in the MCF in the northern region of Hidalgo allows colonization by species with tropical affinities (Fig. 4). The establishment of grazing areas, however, could be detrimental to species exclusively found in the interior of the forests (Charadrahyla taeniopus; Fig. 3), and long-term effects of cattle on the ground could prevent the establishment of viable populations of amphibians due to soil compaction which effects water holding capacity. The local populated areas, therefore should consider legal steps to protect and keep intact the remaining forest patches to preserve the exclusive species living in the interior of these forests.

\section{Acknowledgments}

To J. D. Lara-Tufiño, C. Berriozabal-Islas, and U. HernándezSalinas for their logistic help in the field; to C. Moreno and Vicente Mata-Silva for their comments on the first draft of the manuscript, and to M. Ledezma for his advice on the types of vegetation. We also thank two anonymous reviewers, who greatly improved our manuscript. To the project Fomix-HGO191908 Biodiversidad del Estado de Hidalgo- $3^{\mathrm{a}}$ etapa, for partial support of this research, and finally to Semarnat for providing the scientific permit (\# SGPA/DGVS/02726/10).

\section{References}

Amador, L. (2010). Técnicas para el monitoreo de vertebrados. Guayaquil: Escuela de Biología, Facultad de Ciencias Naturales. Universidad de Guayaquil.

Barragán, F., Moreno, C. E., Escobar, F., Bueno-Villegas, J., \& Halffter, G. (2014). The impact of grazing on dung beetle diversity depends on both biogeographical and ecological context. Journal of Biogeography, 41, 1991-2002.

Bawa, K. S., Kress, W. J., Nadkarini, N. M., Lele, S., Raven, P. H., Janzen, D. H., et al. (2004). Tropical ecosystem into the 21 st century. Science, 306, $227-228$

Cáceres-Andrade, S. P., \& Urbina-Cardona, J. N. (2009). Ensamblajes de anuros de sistemas productivos y bosques en el Piedemonte Llanero, departamento del Meta, Colombia. Caldasia, 31, 175-194.

Canseco-Márquez, L., \& Gutiérrez-Mayen, M. G. (2006). Herpetofauna del municipio de Cuetzalan del Progreso, Puebla. In A. Ramírez-Bautista, L. Canseco-Márquez, \& F. Mendoza-Quijano (Eds.), Inventarios herpetofaunísticos de México: avances en el conocimiento de su biodiversidad (pp. 180-196). México, D.F.: Sociedad Herpetológica Mexicana y Benemérita Universidad de Puebla.

Canseco-Márquez, L., \& Gutiérrez-Mayén, M. G. (2010). Anfibios y reptiles del Valle de Tehuacán-Cuicatlán. México, D.F.: Comisión Nacional para el Conocimiento y Uso de la Biodiversidad, Fundación para la Reserva de la Biósfera Cuicatlán y Benemérita Universidad Autónoma de Puebla.

Carbajal-Cogollo, J. E., \& Urbina-Cardona, J. N. (2008). Patrones de diversidad y composición de reptiles en fragmentos de bosque seco tropical de Córdoba, Colombia. Tropical Conservation Science, 1, 397-416.

Cardinale, B., Duffy, J., González, A., Hooper, D., Perrings, C., Venail, P., et al. (2012). Biodiversity loss and its impact on humanity. Nature, 486, 59-67.

Chao, A., \& Shen, T. (2003). Nonparametric estimation of Shannon's index of diversity when there are unseen species in sample. Environmental and Ecological Statics, 10, 429-443.

Colwell, R. K. (2005). EstimateS: Statistical estimation of species richness and shared species from samples. Version 9.1.. Available online at http://viceroy.eeb.uconn.edu/estimates/ 
Conabio (2010). El bosque mesófilo de montaña en México: amenazas y oportunidades para su conservación y manejo sostenible. México, D.F.: Comisión Nacional para el Conocimiento y Uso de la Biodiversidad.

Cushman, S. (2006). Effects of habitat loss and fragmentation on amphibians: a review and prospectus. Biological Conservation, 128, 231-240.

De Sá, R. O. (2005). Crisis global de biodiversidad: importancia de la diversidad genética y la extinción de los anfibios. Agrociencia, 10, 513-522.

Feinsinger, P. (2003). El diseño de estudios de campo para la conservación de la biodiversidad. Santa Cruz de la Sierra, Bolivia: Fundación de amigos de la naturaleza.

Foley, J. A., DeFries, R., Asner, G. P., Barford, C., Bonan, G., Carpenter, S. R., et al. (2005). Global consequences of land use. Science, 309, 570-574.

Glor, R., Flecker, A., Benard, M. F., \& Power, A. G. (2001). Lizard diversity and agricultural disturbance in a Caribbean forest landscape. Biodiversity and Conservation, 10, 711-723.

Gual-Díaz, M., \& Goyenechea, I. (2014). Anfibios en el bosque mesófilo de montaña en México. In M. Gual-Díaz, \& A. Rendón-Correa (Eds.), Bosques mesófilos de montaña de México: diversidad, ecología y manejo (pp. 249-262). México, D.F.: Comisión Nacional para el Conocimiento y Uso de la Biodiversidad.

Hamilton, L. S., Juvik, J. O., \& Scatena, F. N. (1995). Tropical montane cloud forests. Ecological studies. New York: Springer Verlag.

Hammer, O., Harper, D. A. T., \& Ryan, D. (2001). PAST: Paleontology statistic software package for education and data analysis. Paleontologia Electronica, 4, 1-9

Inegi (Instituto Nacional de Estadística Geografía e Informática). (2009). Prontuario de información geográfica municipal de los Estados Unidos Mexicanos, Tepehuacán de Guerrero, Hidalgo. México, D.F.: Clave geoestadística 13062. Inegi.

Jansen, A., \& Healey, M. (2003). Frog communities and wetland condition: relationships with grazing by domestic livestock along an Australian floodplain river. Biological Conservation, 109, 207-219.

Jost, L. (2006). Entropy and diversity. Oikos, 113, 363-375.

Legendre, P. (2014). Interpreting the replacement and richness difference components of beta diversity. Global Ecology and Biogeography, 23, 1324-1334.

Lira-Noriega, A., Guevara, S., Laborde, J., \& Sánchez-Ríos, G. (2007). Composición florística en potreros de Los Tuxtlas, Veracruz, México. Acta Botanica Mexicana, 80, 59-87.

Manzanilla, J., \& Péfaur, J. E. (2000). Consideraciones sobre métodos y técnicas de campo para el estudio de anfibios y reptiles. Revista de Ecología Latinoamericana, 7(1-2), 17-30.

Mendoza-Quijano, F., Quijano-Manilla, G., \& Mendoza-Paz, R. F. (2006). Análisis fenético de la herpetofauna de los bosques mesófilos de montaña del este de Hidalgo. In A. Ramírez- Bautista, L. Canseco-Márquez, \& F. Mendoza-Quijano (Eds.), Inventarios herpetofaunísticos de México: avances en el conocimiento de su biodiversidad (pp. 99-109). México D.F.: Sociedad Herpetológica Mexicana, Benemérita Universidad de Puebla.

Mensing, D. M., Galatowitsch, S. M., \& Tester, J. R. (1998). Anthropogenic effects on the biodiversity of riparian wetlands of a northern temperate landscape. Journal of Environmental Management, 53, 349-377.
Moreno, C. E. (2001). Métodos para medir la biodiversidad. Manuales y Tesis Sociedad Entomológica Aragonesa, 1, 84. Zaragoza.

Moreno, C. E., Barragán, F., Pineda, E., \& Pavón, N. P. (2011). Reanálisis de la diversidad alfa: alternativas para interpretar y comparar información sobre comunidades ecológicas. Revista Mexicana de Biodiversidad, 82, 1249-1261

Pavlov, D. S., \& Bukvareva, E. N. (2007). Biodiversity and life support of humankind. Herald of the Russian Academy of Sciences, 77, 550-562.

Pineda, E., \& Halffter, G. (2003). Species diversity and habitat fragmentation: Frogs in a tropical montane landscape in Mexico. Biological Conservation, 117, 499-508.

Ponce-Vargas, A., Luna-Vega, I., Alcántara-Ayala, O., \& Ruiz-Jiménez, C. A. (2006). Floristica del bosque mesófilo de Monte Grande, Lolotla, Hidalgo, México. Revista Mexicana de Biodiversidad, 77, 177-190.

Puig, H. (1991). Vegetación de la Huasteca (México) estudio fitogeográfico y ecológico. México D.F.: Instituto de Ecología Asociación Civil.

Ruiz-Jiménez, C. A., Téllez-Valdez, O., \& Luna-Vega, I. (2012). Clasificación de los bosques mesófilos de montaña en México: afinidades de la flora. Revista Mexicana de Biodiversidad, 83, 1110-1144.

Rzedowski, J. (2006). Vegetación de México. México D.F.: Comisión Nacional para el Conocimiento y Uso de la Biodiversidad.

Santos-Barrera, G., \& Urbina-Cardona, J. N. (2011). The role of the matrixedge dynamics of amphibian conservation in tropical montane fragmented landscapes. Revista Mexicana de Biodiversidad, 82, 679-687.

Streicher, J. W., García-Vázquez, U. O., Ponce-Campos, P., Flores-Villela, O., Campbell, J. A., \& Smith, E. N. (2014). Evolutionary relationships amongst polymorphic direct-developing frogs in the Craugastor rhodopis species group (Anura: Craugastoridae). Systematics and Biodiversity, 12, 1-22.

Urbina-Cardona, J. N., \& Lodoño, M. C. (2003). Distribución de la comunidad de herpetofauna asociada a cuatro áreas con diferente grado de perturbación en la isla Gorgona, Pacífico Colombiano. Revista Académica Colombiana Ciencias, 27, 105-114.

Urbina-Cardona, J. N., \& Reynoso, V. H. (2005). Recambio de anfibios y reptiles en el gradiente potrero-borde-interior en la Reserva de Los Tuxtlas, Veracruz, México. In G. Halffter, J. Soberón, P. Koleff, \& A. Melic (Eds.), Sobre diversidad biológica: el significado de las diversidades alfa, beta y gamma (Vol. 4) (pp. 191-207). Zaragoza, España: Monografías Tercer Milenio.

Villavicencio-Nieto, M. A., \& Pérez-Escandón, B. E. (2005). Guía de la flora útil de la Huasteca y la zona Otomí-Tepehua, Hidalgo I. Pachuca: Universidad Autónoma del Estado de Hidalgo, México.

Wanger, T. C., Isakandar, D. T., Motzke, I., Brook, B. W., Sodhi, N. S., Clough, Y., et al. (2010). Effects of land-use change on community composition of tropical amphibians and reptiles in Sulawesi, Indonesia. Conservation Biology, 24, 795-802.

Wilson, L. D., Johnson, J. D., \& Mata-Silva, V. (2013). A conservation reassessment of the amphibians of Mexico based on the EVS measure. Amphibian and Reptile Conservation, 7, 97-127.

Wilson, L. D., Mata-Silva, V., \& Johnson, J. D. (2013). A conservation reassessment of the reptiles of Mexico based on the EVS measure. Amphibian and Reptile Conservation, 7, 1-47. 